\title{
Kinetics, isothermal and thermodynamics studies of electrocoagulation removal of basic dye rhodamine $B$ from aqueous solution using steel electrodes
}

\author{
Abideen Idowu Adeogun ${ }^{1,2}$ - Ramesh Babu Balakrishnan ${ }^{2}$
}

Received: 23 April 2015/Accepted: 26 August 2015/Published online: 7 September 2015

(C) The Author(s) 2015. This article is published with open access at Springerlink.com

\begin{abstract}
Electrocoagulation was used for the removal of basic dye rhodamine $\mathrm{B}$ from aqueous solution, and the process was carried out in a batch electrochemical cell with steel electrodes in monopolar connection. The effects of some important parameters such as current density, $\mathrm{pH}$, temperature and initial dye concentration, on the process, were investigated. Equilibrium was attained after $10 \mathrm{~min}$ at $30^{\circ} \mathrm{C}$. Pseudo-first-order, pseudo-second-order, Elovich and Avrami kinetic models were used to test the experimental data in order to elucidate the kinetic adsorption process; pseudo-first-order and Avrami models best fitted the data. Experimental data were analysed using six model equations: Langmuir, Freudlinch, Redlich-Peterson, Temkin, Dubinin-Radushkevich and Sips isotherms and it was found that the data fitted well with Sips isotherm model. The study showed that the process depends on current density, temperature, $\mathrm{pH}$ and initial dye concentration. The calculated thermodynamics parameters $\left(\Delta G^{\circ}, \Delta H^{\circ}\right.$ and $\left.\Delta S^{\circ}\right)$ indicated that the process is spontaneous and endothermic in nature.
\end{abstract}

Keywords Electrocoagulation - Steel electrodes · Rhodamine B · Kinetics · Thermodynamics · Isotherms

Abideen Idowu Adeogun abuaisha2k3@yahoo.com

1 Department of Chemistry, Federal University of Agriculture, Abeokuta, Nigeria

2 Electrochemical Pollution Control Division, CSIR-Central Electrochemical Research Institute, Karaikudi 630006, India

\section{Introduction}

Advanced technologies for industrialization and urbanization have substantially contributed to environmental degradation, with the aquatic environment greatly affected, through the discharge of industrial wastewaters and domestic wastes (Senthilkumar et al. 2000; Amini et al. 2008). The residual dyes from different sources such as textile, paper and pulp, dye and dye intermediates, pharmaceutical, tannery and kraft bleaching industries are considered as organic coloured pollutants (Rajgopalan 1995; Routh 1998; Kolpin et al. 2000; Ali and Sreekrishnan 2001). These industries utilize large quantities of a number of dyes whose residues lead to large amount of coloured wastewaters, toxic and even carcinogenic, posing serious hazard to aquatic living organisms. Most dyes used in industries are stable to light, heat and oxidation, they are not biologically degradable and are also resistant to aerobic digestion and even when they do, they produce toxic and hazardous products (Sun and Yang 2003; Shawabkeh and Tutunji 2003).

Rhodamine $\mathrm{B}$, a basic dye with molecular formula $\mathrm{C}_{28}$ $\mathrm{H}_{31} \mathrm{~N}_{2} \mathrm{O}_{3} \mathrm{Cl}$, IUPAC Name: N-[9-(ortho-carboxyphenyl)-6(diethylamino)-3H-xanthen-3-yli-dene]diethylammonium chloride) and the chemical structure indicated in Fig. 1, is a highly water soluble red dye of the xanthene class. It is widely used in textiles and food stuffs and is also a wellknown water tracer fluorescent (Richardson et al. 2004). It is harmful when ingested by human beings and animals and causes irritation to the skin, eyes and respiratory tract (Rochat et al. 1978). It cannot be completely degraded by general physicochemical and biological processes because of the complex structures of the aromatic rings that afford high physicochemical, thermal and optical stability (Sun and Yang 2003; Fu et al. 2011). Therefore, most treatments for 


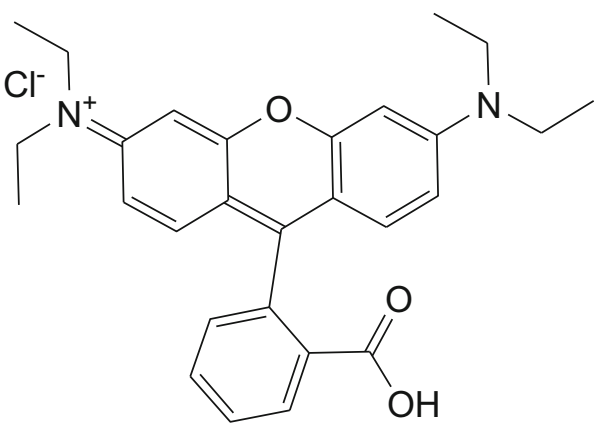

Fig. 1 Structure of rhodamine B

such dye-laden effluents are largely inadequate; however, removal of this dye from industrial wastewaters is a crucial process, from both economic and environmental points of view (Zucca et al. 2008).

Electrochemical techniques, which include electro-oxidation, electrochemical reduction, electro-coagulation, electro-flotation (Carneiro et al. 2005), have been developed for the treatment of organic pollutants in waste water with higher efficiency than any of the biological, physical and chemical processes (Panizza et al. 2001; Wang et al. 2012). Electrocoagulation has been known for some time as a process capable of fractionating a number of organic substances in a rather efficient manner. The coagulants are generated in situ by electro-oxidation of the anode. The mostly used anode materials are iron and aluminium because of their availability and relatively low cost. Electrocoagulation is accomplished in a three-step process as follows: (1) electrolytic reactions at surface of electrodes, (2) formation of coagulants in aqueous phase and (3) adsorption of soluble or colloidal pollutants onto coagulants and removal of them using sedimentation or flotation of flocs when hydrogen gas bubbles were produced at the cathode (Aleboyeh et al. 2008).

In this study, $\mathrm{RhB}$ was removed from aqueous solution in a mono-polar electrochemical cell using aluminium electrodes. The following reactions were envisaged at the electrodes:

Anodic reaction:

$\mathrm{Fe} \rightarrow \mathrm{Fe}^{3+}+3 \mathrm{e}^{-}$

Cathodic reaction:

$3 \mathrm{H}_{2} \mathrm{O}+3 \mathrm{e}^{-} \rightarrow 3 \mathrm{OH}^{-}+3 / 2 \mathrm{H}_{2}$

Overall reaction:

$\mathrm{Fe}^{3+}+3 \mathrm{OH}^{-} \rightarrow \mathrm{Fe}(\mathrm{OH})_{3}$

When these ions are released into solution, the dispersed dye molecules in solution are attached to the hydrous ferric ions, followed by agglomeration and coagulations. The coagulated entities are driven to the surface by the hydrogen gas bubbles produced at the cathode.

This study presents the results of the laboratory scale studies on the electrocoagulation removal of rhodamine $\mathrm{B}$ from aqueous solution. The effects of current density, initial dye concentration, electrolyte concentration, $\mathrm{pH}$ and temperature were studied. Adsorption kinetics of electrocoagulants was analysed with pseudo-first-order, pseudosecond-order, Elovich and Avrami kinetic models. The diffusion mechanism was analysed with intraparticulate diffusion model, while the equilibrium adsorption behaviour was analysed by fitting the equilibrium data with six isotherm models. Thermodynamic parameters such as free energy $(\Delta G)$, enthalpy $(\Delta H)$ and entropy $(\Delta S)$ were also determined to understand the spontaneity of the electrocoagulation process.

\section{Materials and methods}

\section{Dye solution preparation}

Rhodamine B was a product of British Drug House, Poole, England; $1000 \mathrm{mg} \mathrm{L}^{-1}$ aqueous solution of dye was prepared with de-ionized water as the stock solution and was further diluted with de-ionized water to obtain the working standard solutions. The $\mathrm{pH}$ of the solution was adjusted when necessary with aliquots of $1.0 \mathrm{~mol} \mathrm{~L}^{-1}$ of $\mathrm{HCl}$ and $\mathrm{NaOH}$ before the commencement of the experiment. The conductivity of the solution was maintained with $\mathrm{NaCl}$ solution as the electrolyte.

\section{Experimental apparatus and procedures}

Figure 2 depicts the electrocoagulation cell which consists of a $0.6-\mathrm{L}$ glass cell fitted with a polycarbonate cell cover with slots to introduce the electrodes, thermometer and electrolyte; the mild steel electrodes of dimension $4.5 \times 7 \times 0.3 \mathrm{~cm}$ with interelectrode distance of $2 \mathrm{~cm}$ were fully immersed in the $0.5 \mathrm{~L}$ solution of the dye. A regulated direct current (DC) was supplied from a rectifier (0-2 A, 0-35 V; Applab 7711 multi-output). The temperature of the electrolyte was controlled to the desired value with a variation of $\pm 1{ }^{\circ} \mathrm{C}$ by adjusting the temperature knob on the IKA RCT basic magnetic hotplate stirrer and allows equilibration before the commencement of the experiment.

\section{Analytical procedure}

The concentration of the dye in solution was estimated using spectrophotometer (UV-VIS-NIR VARIAN 500 Scan CARY). To compare the dye obtained from the 
Fig. 2 Laboratory-scale electrocoagulation cell

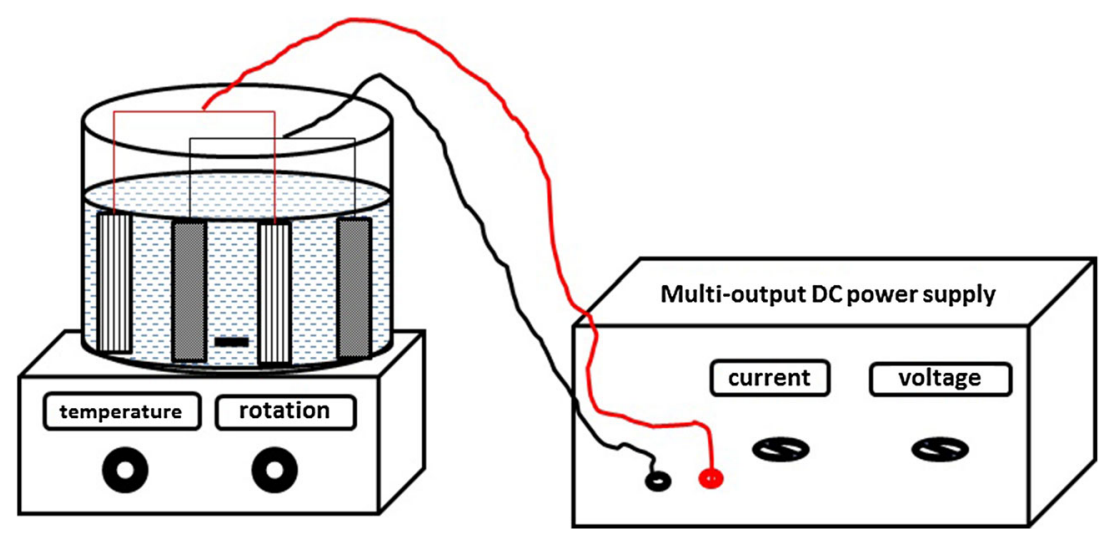

coagulation with the original $\mathrm{RhB}$ dye, the flock is filtered, the residue dried at $105{ }^{\circ} \mathrm{C}$ for $30 \mathrm{~min}$, and then the FTIR of the two samples ( $\mathrm{RhB}$ and residue) was obtained using FTIR spectrophotometer (TENSOR 27 Bruker Optik $\mathrm{GmbH}$, Germany). Nonlinear regression analysis method using a program written on MicroMath Scientist software (Salt Lake City, Utah) was used to obtain the least square fit for all the models.

\section{Equilibrium studies}

The effects of current density, initial dye concentration, electrolyte concentration, $\mathrm{pH}$ and temperature on the electrocoagulation removal of $\mathrm{RhB}$ were studied. Sample solutions were withdrawn at intervals to determine the residual dye concentration by using UV-Vis-NIR spectrophotometer. The amount of dye coagulated at equilibrium, $Q_{\mathrm{e}}\left(\mathrm{mg} \mathrm{g}^{-1}\right)$, was calculated using Eq. 4:

$Q_{\mathrm{e}}=\frac{\left(C_{\mathrm{o}}-C_{\mathrm{e}}\right) V}{W}$

where $C_{\mathrm{o}}\left(\mathrm{mg} \mathrm{L}^{-1}\right)$ is the initial concentration and $C_{\mathrm{e}}$ $\left(\mathrm{mg} \mathrm{L}^{-1}\right)$ is the concentration of the dye at equilibrium in the liquid phase. $V$ is the volume of the solution (L), while $W$ is the mass of the coagulant which can be estimated from Faraday Law according to the Eq. 5:

$W=\frac{M I t}{n F}$

$M$ is the molar mass $\left(\mathrm{g} \mathrm{mol}^{-1}\right)$ of the elements, $I$ is the current (ampere), $t$ is the electrocoagulation time in seconds, $n$ is the number of electrons involved and $F$ is Faraday's constant $\left(96,485.3 \mathrm{C} \mathrm{mol}^{-1}\right)$.

The percentage dye removal as colour was estimated by:

$\%$ Colour Removal $=\frac{\left(\mathrm{Abs}_{\mathrm{o}}-\mathrm{Abs}_{\mathrm{e}}\right) \times 100}{\mathrm{Abs}_{\mathrm{o}}}$

where $\mathrm{Abs}_{\mathrm{o}}$ is the blank absorbance and $\mathrm{Abs}_{\mathrm{e}}$ is the absorbance at equilibrium.

\section{Effect of current density}

Current density is an important factor among the various operating variables, which strongly influences the performance of electrocoagulation process. The amount of coagulants generated is related to the time and current density (Daneshvar et al. 2006). To investigate the effect current density on the removal of ARS, series of experiments were carried out on solutions containing a constant loading of $\mathrm{RhB} 50 \mathrm{mg} \mathrm{L}^{-1}$, at $30^{\circ} \mathrm{C}, \mathrm{pH} 7.0$ and electrolyte concentration maintained with $2 \mathrm{~g} \mathrm{~L}^{-1} \mathrm{NaCl}$, while the current density was varied between 28.6 and $71.5 \mathrm{~A} \mathrm{~m}^{-2}$. Sample solutions were withdrawn at intervals to determine the residual dye concentration.

\section{Effect of initial dye concentration and contact time}

The effect of initial dye concentration and contact time was investigated by performing electrocoagulation on dye solution with known initial concentrations of 10, 20, 30, 40 and $50 \mathrm{mg} \mathrm{L}^{-1}$ at constant temperature of $30{ }^{\circ} \mathrm{C}$, current density $71.5 \mathrm{~A} \mathrm{~m}^{-2}$, pH 7.0 and electrolyte concentration maintained with $2 \mathrm{~g} \mathrm{~L}^{-1} \mathrm{NaCl}$. Samples were withdrawn and analysed for the residual dye from the aqueous at preset time intervals.

\section{Effect of pH on electrocoagulation process}

$\mathrm{pH}$ plays an important role on electrocoagulation process of dye by influencing the chemistry of the coagulant, dye molecule and that of electrochemical process in the solution. To investigate the effect $\mathrm{pH}$, on the removal of $\mathrm{RhB}$, series of experiments were carried out on solutions with initial $\mathrm{pH}$ varied between 5 and 11 . The $\mathrm{pH}$ was adjusted with $0.1 \mathrm{M} \mathrm{NaOH}$ or $0.1 \mathrm{M} \mathrm{HCl}$ and measured using $\mathrm{pH}$ meter. The concentration of the solutions, current density and temperature were held constant at $50 \mathrm{mg} \mathrm{L}^{-1}$, $21.5 \mathrm{~A} \mathrm{~m}^{-2}$ and $30^{\circ} \mathrm{C}$, respectively. 


\section{Effect of electrolyte concentration}

Electrolyte concentration plays significant role in the process of electrocoagulation, to investigate the effect electrolyte concentration on the electrocoagulation removal efficiencies of $\mathrm{RhB}$, experiments were performed on solutions containing a constant loading of RhB $50 \mathrm{mg} \mathrm{L}^{-1}$, at current density of $21.5 \mathrm{~A} \mathrm{~m}^{-2}$ and $\mathrm{pH} 7$, while the concentrations of $\mathrm{NaCl}$ were varied between 2 and $5 \mathrm{~g} \mathrm{~L}^{-1}$.

\section{Adsorption isotherms}

The equilibrium data from this study were described with six adsorption isotherms models i.e. Langmuir (1918), Freundlich (1906), Tempkin and Pyzhev (1940) Dubinin and Radushkevich (1947), Sips (1948) and Redlich and Peterson (1959). The acceptability and suitability of the isotherm equation to the equilibrium data were based on the values of the correlation coefficients $R^{2}$ estimated from linear regression of the least square fit statistic on MicroMath Scientist software.

\section{Langmuir isotherms}

The Langmuir isotherm equation is based on the following assumptions: (1) that the entire surface for the adsorption has the same activity for adsorption, (2) that there is no interaction between adsorbed molecules and (3) that all the adsorption occurs by the same mechanism and the extent of adsorption is less than one complete monomolecular layer on the surface. The Langmuir equation is given by Eq. 7 (Langmuir 1918):

$Q_{\mathrm{eq}}=\frac{Q_{o} b C_{\mathrm{e}}}{1+b C_{\mathrm{e}}}$

where $Q_{\mathrm{o}}$ is the maximum amount of the dye molecule per unit weight of the coagulant to form a complete monolayer on the surface, $C_{\mathrm{e}}\left(\mathrm{mg} \mathrm{g}^{-1}\right)$ is the concentration of the dye remaining in solution at equilibrium and $b$ is equilibrium constant $\left(\mathrm{dm}^{3} \mathrm{mg}^{-1}\right)$. The shape of Langmuir isotherm can be used to predict whether a process is favourable or unfavourable in a batch adsorption process. The essential features of the Langmuir isotherm can be expressed in terms of a dimensionless constant separation factor $\left(R_{\mathrm{L}}\right)$ that can be defined by the following relationship (Aniruldhan and Radhakrishnan 2008):

$R_{L}=\frac{1}{1+b C_{0}}$

where $C_{\mathrm{o}}$ is the initial concentration $\left(\mathrm{mg} \mathrm{L}^{-1}\right)$ and $b$ is the Langmuir equilibrium constant $\left(\mathrm{L} \mathrm{mg}^{-1}\right)$. The value of separation parameter $R_{\mathrm{L}}$ provides important information about the nature of adsorption. The value of $R_{\mathrm{L}}$ indicated the type of Langmuir isotherm to be irreversible if $R_{\mathrm{L}}=0$, favourable when $0<R_{\mathrm{L}}<1$, linear when $R_{\mathrm{L}}=1$ and unfavourable when $R_{\mathrm{L}}>1$. However, it can be explained apparently that when $b>0$, sorption system is favourable (Chen et al. 2008).

\section{Freundlich isotherm}

The Freundlich isotherm is an empirical equation based on sorption on a heterogeneous surface. It is commonly presented as:

$Q_{\mathrm{eq}}=K_{\mathrm{F}} C_{\mathrm{e}}^{1 / n}$

where $K_{\mathrm{F}}$ and $n$ are the Freundlich constants related to the adsorption capacity and intensity of the sorbent, respectively (Bello et al. 2008; Adeogun et al. 2012).

\section{Redlich-Peterson isotherm}

A three-parameter Redlich-Peterson equation has been proposed to improve the fit by the Langmuir or Freundlich equation and is given by Eq. 10 .

$Q_{\mathrm{eq}}=\frac{Q_{\mathrm{o}} C_{\mathrm{e}}}{1+K_{\mathrm{R}} C_{\mathrm{e}}^{\beta}}$

where $K_{\mathrm{R}}$ and $\beta$ are the Redlich-Peterson parameters, $\beta$ lies between 0 and 1 (Vaghetti et al. 2009). For $\beta=1$, Eq. (10) converts to the Langmuir form.

\section{Tempkin isotherm model}

Temkin isotherm model was also used to fit the experimental data. Unlike the Langmuir and Freundlich equations, the Temkin isotherm takes into account the interaction between sorbent and adsorbent. It is based on the assumption that the free energy of sorption is a function of the surface coverage (Chen et al. 2008). The Tempkin isotherm is represented as in Eq. 11:

$Q_{\mathrm{e}}=\frac{R T}{b_{T}} \ln a_{T} C_{\mathrm{e}}$

where $C_{\mathrm{e}}$ is concentration of dye in solution at equilibrium (mg L $\left.{ }^{-1}\right), Q_{\mathrm{e}}$ is the amount of dye molecule coagulated at equilibrium $\left(\mathrm{mg} \mathrm{g}^{-1}\right), T$ is the temperature $(\mathrm{K})$, and $R$ is the ideal gas constant $\left(8.314 \mathrm{~J} \mathrm{~mol}^{-1} \mathrm{~K}^{-1}\right)$ and ' $a_{T}$ ' and ' $b_{T}$ ' are constants relating to binding constant $\left(\mathrm{L} \mathrm{mg}^{-1}\right)$ equilibrium corresponding to the maximum bonding energy and the heat of adsorption, respectively.

\section{The Dubinin-Radushkevich isotherm}

The Dubinin-Radushkevich model (Dubinin and Radushkevich 1947) was chosen to estimate the 
heterogeneity of the surface energies and also to determine the nature of adsorption processes as physical or chemical. The D-R sorption isotherm is more general than the Langmuir isotherm as its derivation is based on ideal assumptions such as equipotent of the sorption sites, absence of stoic hindrance between sorbed and incoming particles and surface homogeneity on microscopic level (Weber and Morris 1963; Malik 2004). D-R isotherm is represented by Eq. 12 .

$Q_{e}=Q_{m} e^{-\beta \varepsilon^{2}}$

where $Q_{m}$ is the theoretical saturation capacity $\left(\mathrm{mol} \mathrm{g}^{-1}\right), \beta$ is a constant related to the mean free energy of adsorption per mole of the adsorbate $\left(\mathrm{mol}^{2} \mathrm{~J}^{-2}\right)$, and $\varepsilon$ is the Polanyi potential given by the relation; $\varepsilon=\ln \left(1+1 / C_{\mathrm{e}}\right) . C_{\mathrm{e}}$ is the equilibrium concentration of dye in solution $\left(\mathrm{mg} \mathrm{L}^{-1}\right), R$ ( $\mathrm{J} \mathrm{mol}^{-1} \mathrm{~K}^{-1}$ ) is the gas constant and $T(\mathrm{~K})$ is the absolute temperature. The constant $\beta$ gives an idea about the mean free energy $E\left(\mathrm{~kJ} \mathrm{~mol}^{-1}\right)$ of adsorption per molecule of the adsorbate when it is transferred to the surface of the solid from relationship (Kundu and Gupta 2006).

$E=(2 \beta)^{-0.5}$

If the magnitude of $E$ is between 8 and $16 \mathrm{~kJ} \mathrm{~mol}^{-1}$, the process is chemisorption, while values of $E<8 \mathrm{~kJ} \mathrm{~mol}^{-1}$ suggest a physical process.

\section{The Sips isotherm}

The Sips isotherm model is a combined form of the Langmuir and Freundlich expressions deduced for predicting the heterogeneous adsorption systems and circumventing the limitation of the rising adsorbate concentration associated with the Freundlich isotherm model (Sips 1948). At high adsorbate concentration, it predicts monolayer adsorption characteristics of Langmuir isotherm, while at low adsorbate concentration, it reduces to Freundlich isotherm. The Sips model is expressed as Eq. 14:

$Q_{\mathrm{eq}}=\frac{Q_{\mathrm{o}}\left(k_{\mathrm{s}} C_{\mathrm{e}}\right)^{m_{\mathrm{s}}}}{1+\left(k_{\mathrm{s}} C_{\mathrm{e}}\right)^{m_{\mathrm{s}}}}$

where $k_{\mathrm{s}}$ is the Sips isotherm model constant and $\mathrm{m}_{\mathrm{s}}$ is the Sips isotherm model exponent.

\section{Electrocoagulation kinetics studies}

Since the amount of coagulant can be estimated for a given time, the pollutant removal can be modelled using an adsorption phenomenon. The procedures for the kinetics studies were basically identical to those of equilibrium tests. The aqueous samples were taken at preset time intervals, and the concentrations of the dye were similarly determined. The amount of dye removed at time $t, Q_{t}$ $\left(\mathrm{mg} \mathrm{g}^{-1}\right)$, was calculated using Eq. 15:

$Q_{t}=\frac{\left(C_{o}-C_{t}\right) V}{W}$

where $C_{o}\left(\mathrm{mg} \mathrm{L}^{-1}\right)$ is the initial concentration and $C_{t}$ ( $\mathrm{mg} \mathrm{L}^{-1}$ ) is the concentration of the dye at time $t$ in the liquid phase. $V$ is the volume of the solution (L), and $W$ is the mass of $\mathrm{Fe}(\mathrm{OH})_{3}$ calculated as stated in Eq. 5 above. In order to investigate the mechanisms of the adsorption process, pseudo-first order, pseudo-second-order, Avrami and Elovich models, respectively, were applied to describe the kinetics of adsorption of $\mathrm{RhB}$ to in situ-generated $\mathrm{Fe}(\mathrm{OH})_{3}$ during the electrocoagulation process. A model is adjudged best fit and selected based on statistical parameters.

\section{Pseudo-first-order kinetics model}

A simple kinetics analysis of the process under the pseudofirst-order assumption is given in Eq. 8 below (Adeogun et al. 2011; Lin et al. 2011):

$\frac{\mathrm{d} Q}{\mathrm{~d} t}=k_{1}\left(Q_{e}-Q_{t}\right)$

where $Q_{\mathrm{e}}$ and $Q_{t}$ are the dye concentrations $\left(\mathrm{mg} \mathrm{g}^{-1}\right)$ at equilibrium and at time $t(\mathrm{~min})$, respectively, $k_{1}$ is the adsorption rate constant $\left(\mathrm{min}^{-1}\right)$, and $t$ is the contact time (min). The integration of Eq. 16 with initial concentrations, $Q_{t}=0$ at $t=0$, and $Q_{t}=Q_{t}$ at $t=t$, yields Eq. 17 below:

$\ln \left(Q_{\mathrm{e}}-Q_{t}\right)=\ln Q_{\mathrm{e}}-k_{1} t$

Upon rearrangement, Eq. 17 becomes:

$Q_{t}=Q_{\mathrm{e}}\left(1-\mathrm{e}^{-k_{1} t}\right)$

The values of $Q_{\mathrm{e}}$ and $k_{1}$ were calculated from the least square fit of $Q_{t}$ versus $t$ at different dye concentrations.

\section{Pseudo-second-order kinetics model}

A pseudo-second-order kinetics model is based on equilibrium adsorption (Adeogun et al. 2010, 2011) and it is expressed in Eq. 19 below:

$t / Q_{t}=1 / k_{2} Q_{\mathrm{e}}^{2}+\left(1 / Q_{t}\right) t$

The expression above can also be rearranged to give Eq. 20 below:

$Q_{t}=\frac{k_{2} Q_{\mathrm{e}}^{2} t}{1+k_{2} Q_{\mathrm{e}} t}$

where $k_{2}\left(\mathrm{~g} \mathrm{mg}^{-1} \mathrm{~min}^{-1}\right)$ is the rates constant of pseudosecond-order adsorption. The values of $Q_{\mathrm{e}}$ and $k_{2}$ were calculated from the least square fit of $Q_{t}$ versus $t$ at different dye concentrations. 


\section{Elovich model}

Elovich model is a kinetic equation describing a chemisorption process (Zeldowitsch 1934), and it describes the rate of adsorption which decreases exponentially with an increase in the adsorbed. It is generally expressed in Eq. 21 (Perez-Marin et al. 2007):

$Q_{t}=1 / \beta \ln (\alpha \beta * t)$

where $\alpha$ is the initial adsorption rate $\left(\mathrm{mg} \mathrm{g}^{-1} \min ^{-1}\right), \beta$ is the desorption constant $\left(\mathrm{g} \mathrm{mg}^{-1}\right)$. The value of reciprocal of $\beta$ reflects the number of sites available for adsorption, whereas the value of adsorbed quantity when $\ln t$ is equal to zero is given by $1 / \beta \ln (\alpha \beta)$.

\section{Avrami kinetic model}

The Avrami kinetic model equation is an adaptation of the kinetic thermal decomposition modelling (Avrami 1940). The model is expressed as:

$Q_{t}=Q_{e}\left\{1-\exp \left(-k_{a v} t^{n_{a v}}\right)\right\}$

where $Q_{t}$ is the adsorption fraction at time $t ; k_{a v}$ is the adjusted kinetic constant; and $n_{a v}$ is a constant related to the adsorption mechanism, and its value can be used to verify possible interactions of the adsorption mechanisms in relation to the contact time and the temperature.

\section{Statistical test for the kinetics data}

The acceptability and hence the best fit of the kinetic data were based on the square of the correlation coefficients $R^{2}$ and the percentage error function which measures the differences (\% SSE) in the amount of the dye concentration coagulated at equilibrium predicted by the models $\left(Q_{\text {cal }}\right)$ and (i.e. $Q_{\exp }$ ) measured experimentally. The validity of each model was determined by the sum of error squares (SSE, \%) given by:

$\% \mathrm{SSE}=\sqrt{\frac{\left(\left(Q_{(\mathrm{exp})}-Q_{(\mathrm{cal})}\right) / Q_{\text {exp }}\right)^{2}}{N-1}} \times 100$

$N$ is the number of data points. The higher the value of $R^{2}$ and the lower the value of SSE, the better fitted the data.

\section{Intraparticulate diffusion model}

Due to the fact that the diffusion mechanism cannot be obtained from the kinetics model, the intraparticulate diffusion model (Lin et al. 2011) was also tested. The initial rate of the intraparticulate diffusion is given by the following expression:
$Q_{t}=K_{\mathrm{id}} t^{0.5}+C_{\mathrm{i}}$

where $K_{\text {id }}$ is the intraparticulate diffusion rate constant $\left(\mathrm{mg} \mathrm{g}^{-1} \min ^{-0.5}\right.$ ) and $C_{\mathrm{i}}$ is intercept and a measure of surface thickness.

\section{Thermodynamics of electrocoagulation process}

The thermodynamics parameters, i.e. $\Delta G^{\circ}, \Delta H^{\circ}$ and $\Delta S^{\circ}$ were estimated using the following relation:

$\Delta G^{o}=-R T \ln K_{d}$

$\ln K_{d}=\frac{\Delta S^{\circ}}{R}-\frac{\Delta H^{\circ}}{R T}$

The equilibrium constant, $K_{\mathrm{d}}$, is obtained from the value of $Q_{\mathrm{e}} / C_{\mathrm{e}}$ at different temperature equilibrium study. Van't Hoff plot of $\ln K_{\mathrm{d}}$ against the reciprocal of temperature (1/ $T$ ) should give a straight line with intercept as $\frac{\Delta S^{\circ}}{R}$ and slope as $\frac{\Delta H^{\circ}}{R}$.

\section{Result and discussion}

\section{Batch equilibrium studies}

\section{Effect of current density}

Current density determines the coagulant production rate, adjusts the rate and size of the bubble production and hence affects the growth of flocs (Daneshvar et al. 2003; Mollah et al. 2004). The effect of current density on the efficiency of colour removal by electrocoagulation process was carried out using various current densities. Figure 3 shows the plot of current density versus the percentage colour removal by the electrocoagulation process. From the figure, it is glaring that as the current density is increased, the rate of colour removal also increased from 28 to $71 \mathrm{~A} \mathrm{~m}^{-2}$, and the $\%$ colour removal increases from 50 to $90 \%$. Increasing current density results in a corresponding increase in the production of coagulant in the solution leading to high efficiency.

\section{Effect of $p H$ on electrocoagulation process}

$\mathrm{pH}$ is an important parameter influencing the performance of the EC process (Daneshvar et al. 2003), and it affects the chemistry of both the coagulants, dye molecules and that of electrochemical process in the solution. The colour removal percentages for dye solutions with various initial $\mathrm{pH}$ values are shown in Fig. 4. The colour removal efficiency is optimum at the at $\mathrm{pH}$ range of 6.5 and 7.5 with roughly $95.5 \%$ colour removal efficiency. 


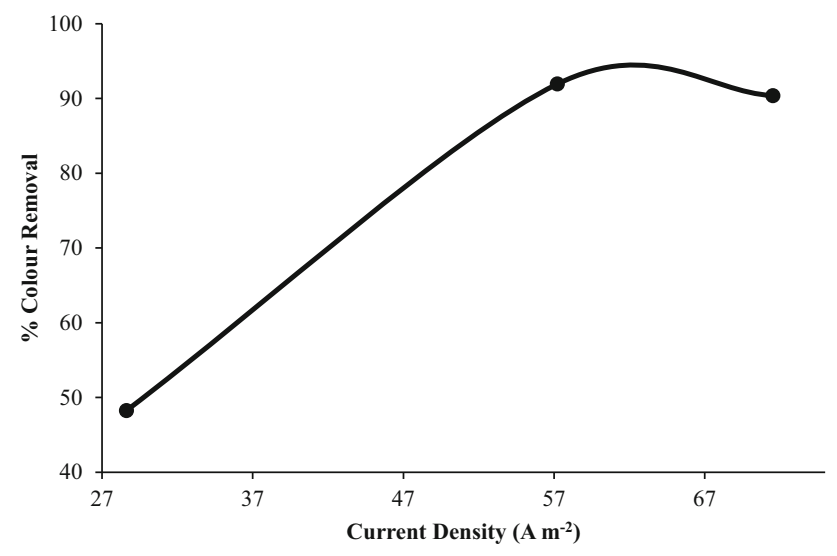

Fig. 3 Effect of current density on \% colour removal, initial dye conc: $50 \mathrm{mg} \mathrm{L}^{-1} \mathrm{pH}$ : 7.0 ; $\mathrm{NaCl}$ conc: $2 \mathrm{~g} \mathrm{~L}^{-1}$; temperature: $30{ }^{\circ} \mathrm{C}$
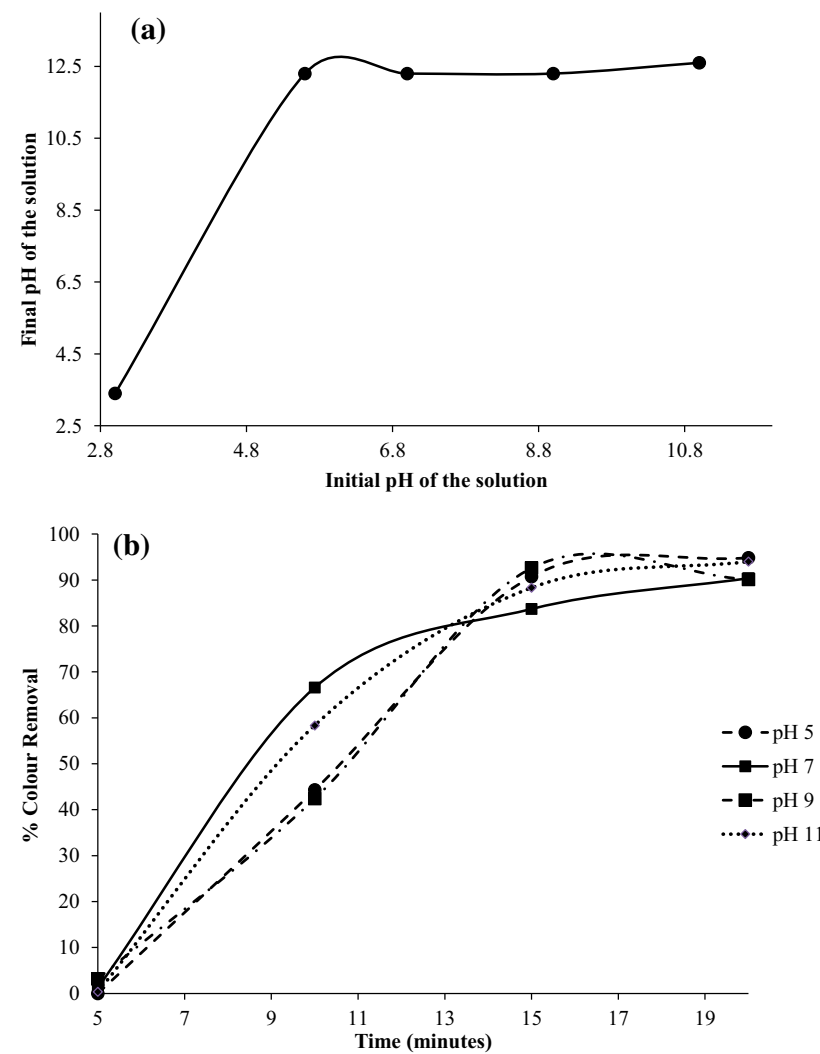

Fig. 4 a Effect of initial pH on \% colour removal, b initial and final $\mathrm{pH}$ of the dye solution. Initial dye conc: $50 \mathrm{mg} \mathrm{L}^{-1}$; current density: $71.5 \mathrm{~A} \mathrm{~m}^{-2}$; $\mathrm{NaCl}$ conc: $2 \mathrm{~g} \mathrm{~L}^{-1}$; temperature: $30{ }^{\circ} \mathrm{C}$

\section{Effect of electrolyte concentration}

Solution conductivity influences the current efficiency, cell voltage and consumption of electrical energy in electrolytic cells. The use of $\mathrm{NaCl}$ to increase solution conductivity is also accompanied by the production of chloride ions that reduce the effects of other anions, such as bicarbonate and

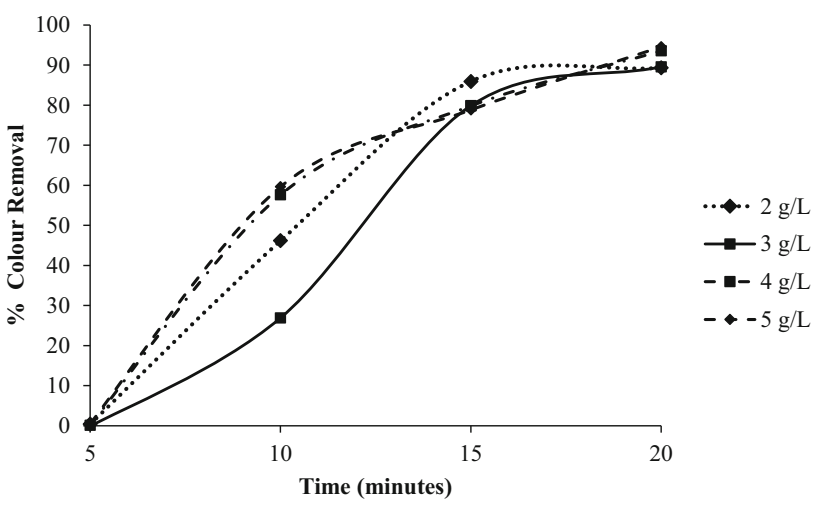

Fig. 5 Effect of electrolyte concentration on \% colour removal, initial dye conc: $50 \mathrm{mg} \mathrm{L}^{-1}$; current density: $71.5 \mathrm{~A} \mathrm{~m}^{-2}$; $\mathrm{pH}$ 7.0; temperature: $30{ }^{\circ} \mathrm{C}$

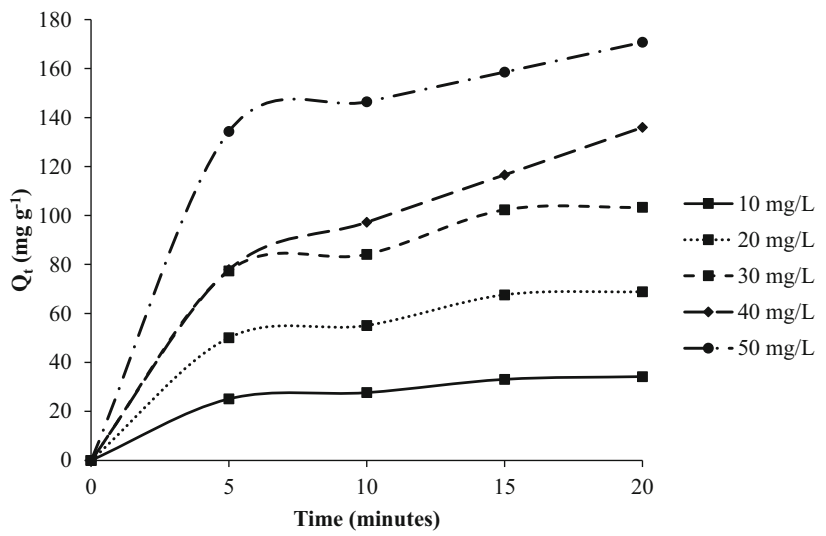

Fig. 6 Effect of initial concentration on the electrocoagulation removal of rhodamine blue. $\mathrm{pH} 7.0$; current density: $71.5 \mathrm{~A} \mathrm{~m}^{-2}$; $\mathrm{NaCl}$ conc: $2 \mathrm{~g} \mathrm{~L}^{-1}$; temperature: $30{ }^{\circ} \mathrm{C}$

sulphate which may lead to precipitation of $\mathrm{Ca}^{2+}$ leading to ohmic resistance of the electrochemical cell (Daneshvar et al. 2006). Figure 5 shows that the colour removal efficiency also increases from 84 to $94 \%$ as the electrolyte concentration moves to $2 \mathrm{~g} \mathrm{~L}^{-1}$, and a further increase in electrolyte concentration beyond these values does not significantly affect the removal efficiency of the dye from the solution. The results also suggest that high colour removal percentage with low cell voltages and low energy consumption can be obtained at $\mathrm{NaCl}$ concentration of $2 \mathrm{~g} \mathrm{~L}^{-1}$.

\section{Effect of initial dye concentrations}

The effect of initial dye concentration on the electrocoagulation removal of $\mathrm{RhB}$ is shown in Fig. 6 for dye concentrations increasing from 10 to $50 \mathrm{mg} \mathrm{L}^{-1}$. The process showed rapid removal in the first $5 \mathrm{~min}$ for all the concentrations studied. The efficiency of the process increases

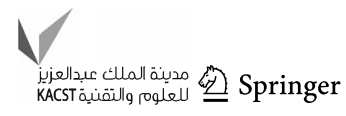



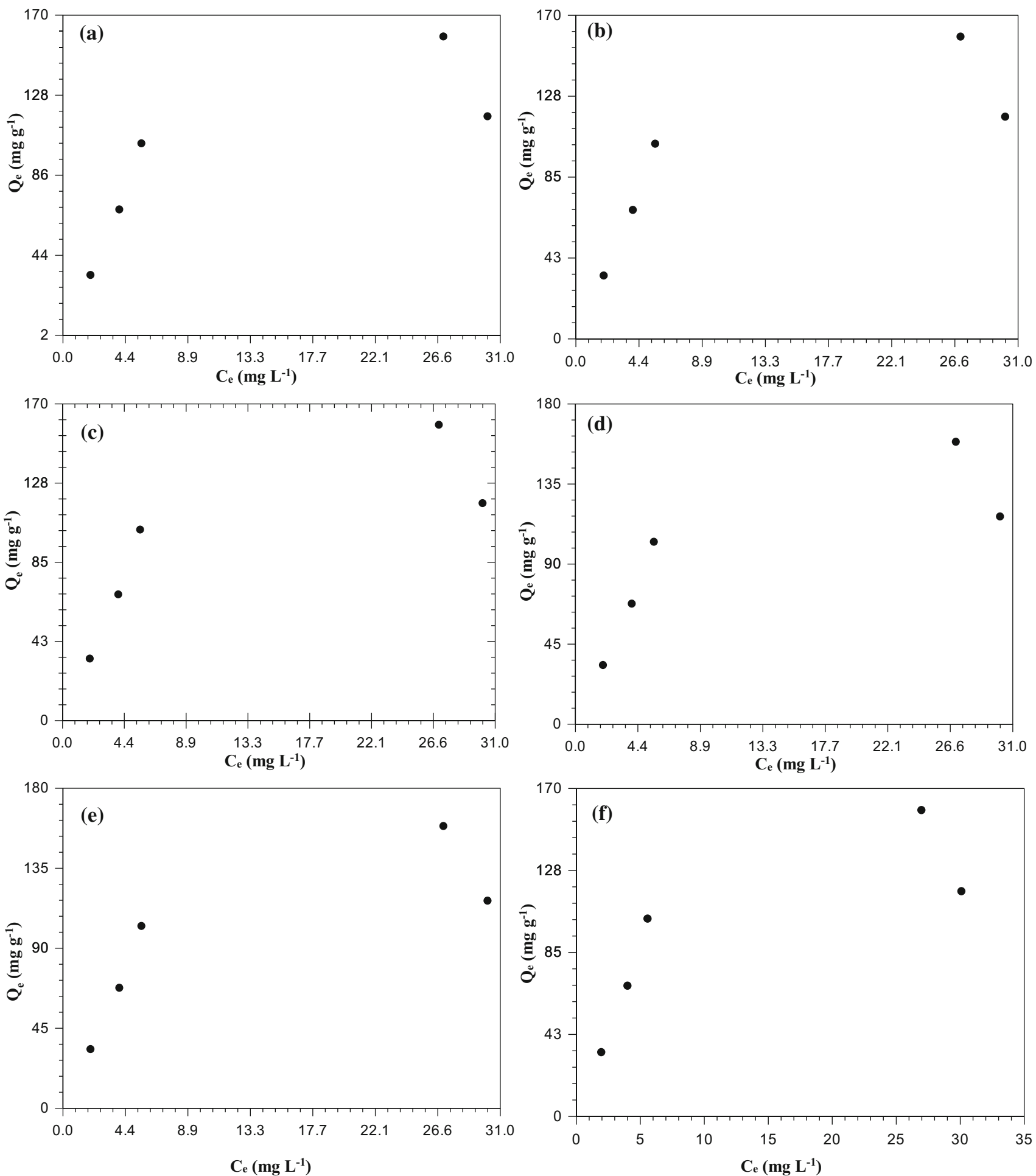

Fig. 7 Isothermal fits for electrocoagulation removal of rhodamine B: a Langmuir, b Freudlinch, c Temkin, d Dubinin-Radushkevich, e Redlich-Peterson and f Sip isotherms

from 25.1 to $134.3 \mathrm{mg} \mathrm{g}^{-1}$ as the initial concentration increases from 10 to $50 \mathrm{mg} \mathrm{L}^{-1}$. As there is no significant difference in the amount coagulated after $20 \mathrm{~min}$ of the process, a steady-state approximation was assumed and a quasi-equilibrium situation was reached. The electrocoagulation curves were single, smooth and continuous, leading to saturation. This is an indication of possible monolayer coverage on the surface of electrochemically generated coagulant (Langmuir 1918; Saha and Sanyal 2010). 
Table 1 Langmuir, Freudlinch, Redlich-Peterson, Tempkin, Dubinin-Radushkevich and Sip's isotherms for the removal of bromophenol blue

\begin{tabular}{|c|c|c|c|c|c|c|c|c|c|c|c|}
\hline \multicolumn{2}{|l|}{ Langmuir } & \multicolumn{2}{|l|}{ Freudlinch } & \multicolumn{2}{|c|}{ Redlich-Peterson } & \multicolumn{2}{|l|}{ Temkin } & \multicolumn{2}{|c|}{ Dubinin-Radushkevich } & \multicolumn{2}{|l|}{ Sips } \\
\hline $\mathrm{Q}_{\max }\left(\mathrm{mg} \mathrm{g}^{-1}\right)$ & 163.36 & $\mathrm{~K}_{\mathrm{f}}\left(\mathrm{mg} \mathrm{g}^{-1} \min ^{-1 / n}\right)$ & 42.87 & $\mathrm{Q}_{0}\left(\mathrm{~L} \mathrm{mg}^{-1}\right) \mathrm{g}$ & 143.51 & $\mathrm{a}_{\mathrm{T}}\left(\mathrm{L} \mathrm{g}^{-1}\right)$ & 1.75 & $\mathrm{Q}\left(\mathrm{mg} \mathrm{g}^{-1}\right)$ & 137.36 & $\mathrm{Q}_{\max }\left(\mathrm{mg} \mathrm{g}^{-1}\right)$ & 139.95 \\
\hline $\mathrm{b}\left(\mathrm{L} \mathrm{mg}^{-1}\right)$ & 0.200 & $1 / \mathrm{n}$ & 0.35 & $\mathrm{~K}_{\mathrm{R}}\left(\mathrm{L} \mathrm{g}^{-1}\right)$ & 0.96 & $\mathrm{~b}_{\mathrm{T}}$ & 69.94 & $\beta\left(\mathrm{mol} \mathrm{J}^{-1}\right)^{2}$ & $1.77 \times 10^{-6}$ & $\mathrm{~K}_{\mathrm{s}}\left(\mathrm{L} \mathrm{mg}^{-1}\right)^{\mathrm{ms}}$ & 0.266 \\
\hline$R_{\mathrm{L}}$ & 0.176 & $R^{2}$ & 0.961 & $\beta$ & 0.243 & $R^{2}$ & 0.970 & $\mathrm{E}\left(\mathrm{kJ} \mathrm{mol}^{-1}\right)$ & 532.12 & $\mathrm{~m}_{\mathrm{s}}$ & 2.07 \\
\hline$R^{2}$ & 0.974 & & & $R^{2}$ & 0.973 & & & $R^{2}$ & 0.978 & $R^{2}$ & 0.982 \\
\hline
\end{tabular}

Current density: $71.5 \mathrm{~A} \mathrm{~m}^{-2}$; $\mathrm{NaCl}$ conc: $2 \mathrm{~g} \mathrm{~L}^{-1}$; temperature: $30{ }^{\circ} \mathrm{C}$; $\mathrm{pH}: 7.0$
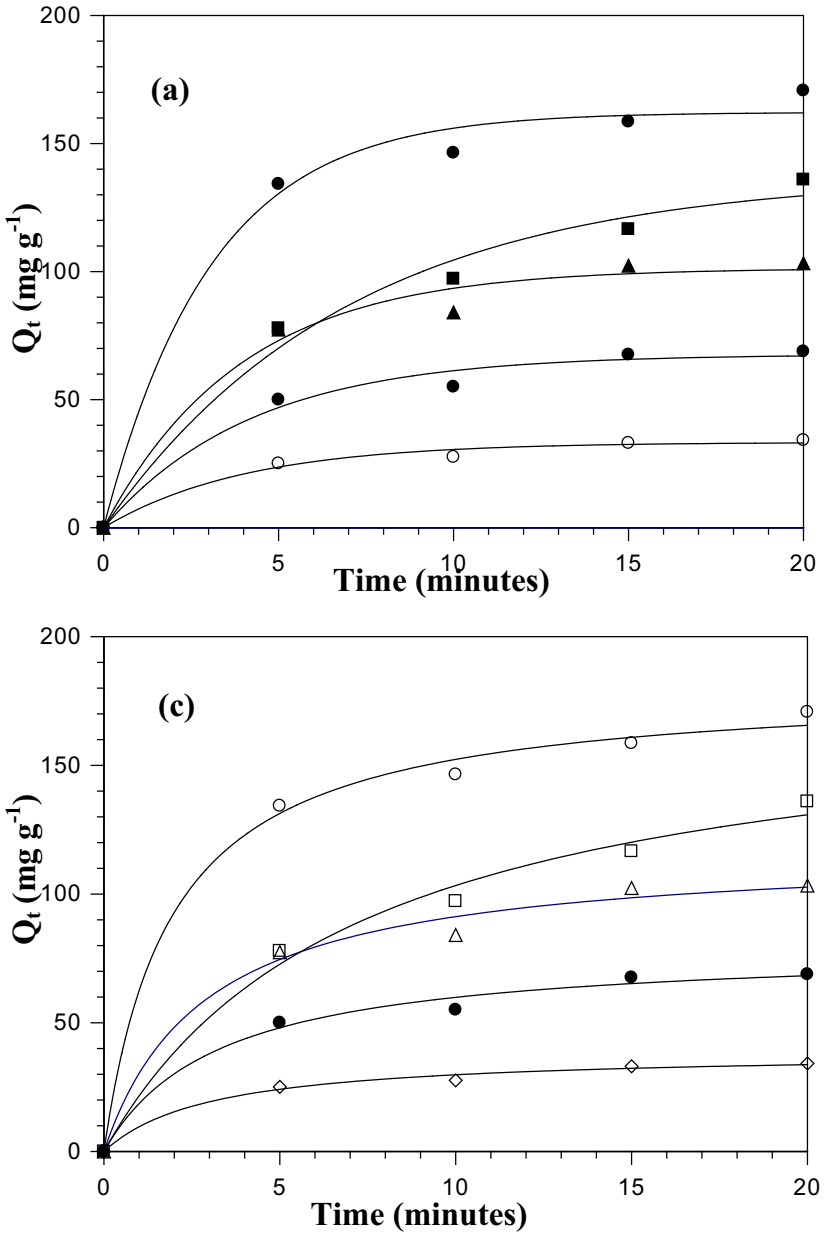
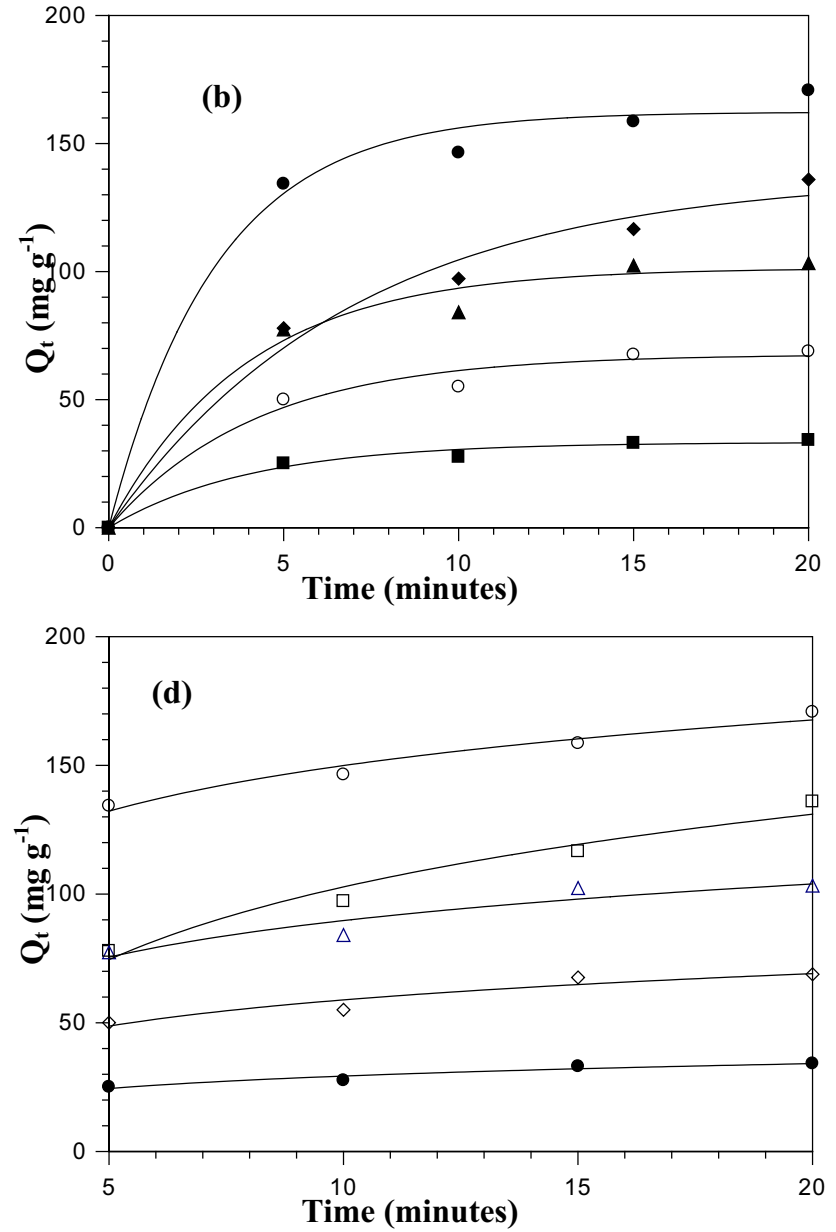

Fig. 8 Kinetics of electrocoagulation removal of rhodamine a pseudo-first-order kinetic, b Avrami, $\mathbf{c}$ pseudo-second-order kinetic and $\mathbf{d}$ Elovich kinetic model fit

\section{Adsorption study}

\section{Adsorption isotherms}

The adsorption data obtained at different initial dye concentrations were fitted into six different isotherm models as shown in Fig. 7. The adsorption data fitted well with Dubinin-Radushkevich and Sip's isotherms with the highest $R^{2}$ (Table 1). The $Q_{m}$ value of $163.36 \mathrm{mg} \mathrm{g}^{-1}$ obtained for the Langmuir isotherm model was compared with other isotherm $Q_{m}$ values, and this comparison shows that the Dubinin-Radushkevich isotherm has a similar $Q_{m}$ value with the Langmuir isotherm (Table 1). The $n$ value of $>1$ and the $R_{\mathrm{L}}$ of $<1$ obtained for Freudlinch and Langmuir isotherms indicate that the adsorption is favourable. 


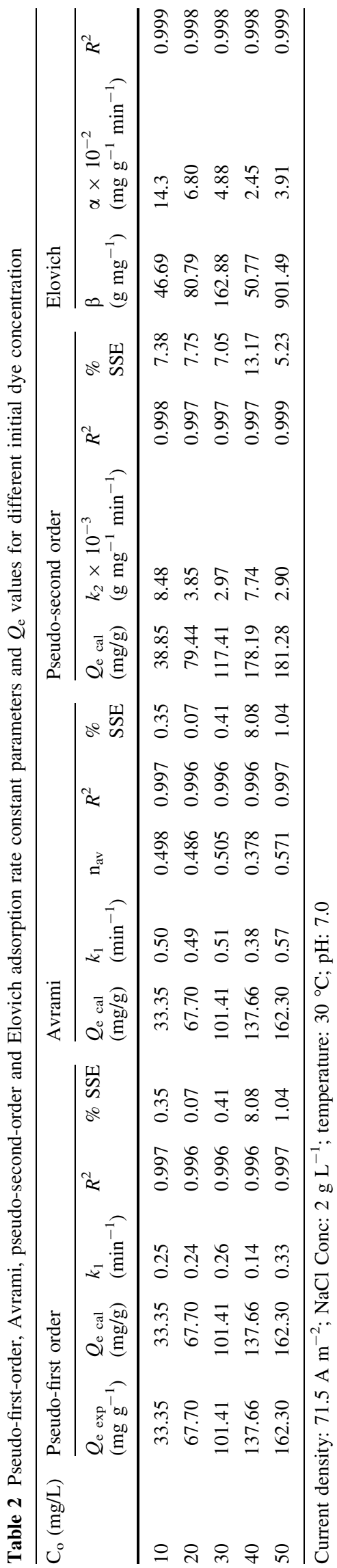

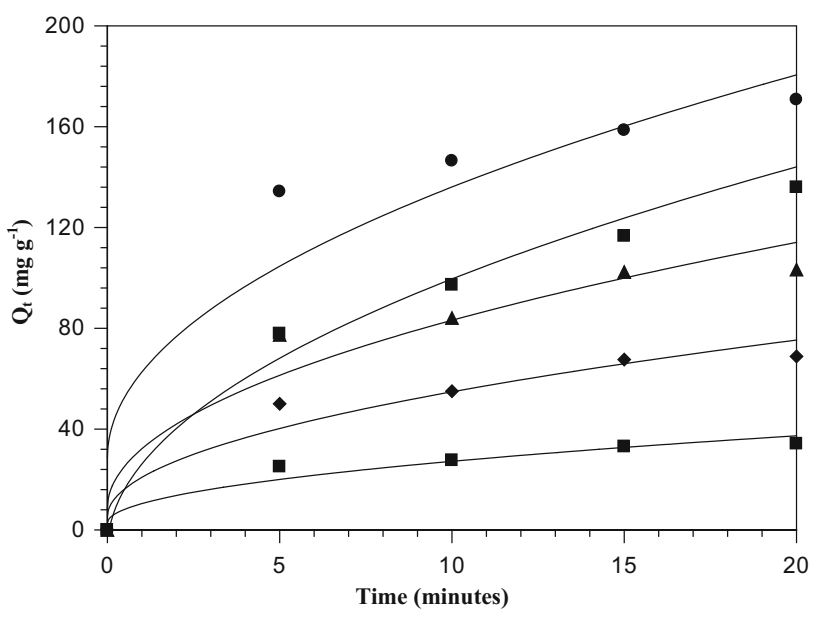

Fig. 9 Intraparticulate diffusion fit for electrocoagulation removal of rhodamine blue dye

\section{Electrocoagulation kinetics}

The plots of four different kinetic models used to explain the adsorption data are shown in Fig. 8, the pseudo-firstorder kinetic models fit well with experimental data when compared with other models (Table 2). The rate constant from all the models decreases with initial dye concentration up to $40 \mathrm{mg} \mathrm{L}^{-1}$ before decreasing at $50 \mathrm{mg} \mathrm{L}^{-1}$. This shows that at higher initial concentration, the electrostatic interaction decreases at the site, thereby lowering the adsorption rate. The behaviour of Elovich constant shows that the process of adsorption is more than one mechanism.

\section{Adsorption mechanism}

The mechanism of adsorption was investigated by subjecting the data to intraparticulate diffusion model. The plots are shown in Fig. 9. The linearity of the plot is not over the whole time range, and rather, they exhibit multilinearity revealing the existence of two successive adsorption steps. The first stage is faster than the second, and it is attributed to the external surface adsorption referred to as the boundary layer diffusion. Thereafter, the second linear part is attributed to the intraparticulate diffusion stage; this stage is the rate-controlling step. Table 3 shows the intraparticulate model constants for the electrocoagulation removal of RhB dye. The $K_{d i}$ values were found to increase from first stage of adsorption towards the second stage. The increase in dye concentration results in an increase in the driving force, thereby increasing the dye diffusion rate.

\section{Thermodynamic parameters}

The free energy change, $\Delta G$, is obtained from Eqs. 25 and 26 according to the van't Hoff linear plots of $\ln K_{d}$ versus 
Table 3 Intraparticle diffusion model's parameters for the removal of bromophenol blue

\begin{tabular}{|c|c|c|c|c|c|c|}
\hline \multirow[t]{2}{*}{ Co $(\mathrm{mg} / \mathrm{L})$} & \multicolumn{6}{|l|}{ Intraparticulate } \\
\hline & $k_{1 d}\left(\mathrm{mg} \mathrm{g}^{-1} \min ^{-0.5}\right)$ & $\mathrm{C}_{1}\left(\mathrm{mg} \mathrm{g}^{-1}\right)$ & $R^{2}$ & $k_{2 d}\left(\mathrm{mg} \mathrm{g}^{-1} \min ^{-0.5}\right)$ & $\mathrm{C}_{2}\left(\mathrm{mg} \mathrm{g}^{-1}\right)$ & $R^{2}$ \\
\hline 10 & 2.766 & 3.7579 & 0.8187 & 0.656 & 21.829 & 0.874 \\
\hline 20 & 5.506 & 7.509 & 0.818 & 1.377 & 43.171 & 0.817 \\
\hline 30 & 8.4125 & 11.78 & 0.81 & 1.919 & 67.81 & 0.788 \\
\hline 40 & 9.724 & 9.754 & 0.892 & 3.872 & 58.52 & 0.999 \\
\hline 50 & 14.65 & 20.36 & 0.812 & 2.4287 & 122.16 & 0.999 \\
\hline
\end{tabular}

Current density: $71.5 \mathrm{~A} \mathrm{~m}^{-2}$; $\mathrm{NaCl}$ Conc: $2 \mathrm{~g} \mathrm{~L}^{-1}$; temperature: $30^{\circ} \mathrm{C} ; \mathrm{pH}: 7.0$

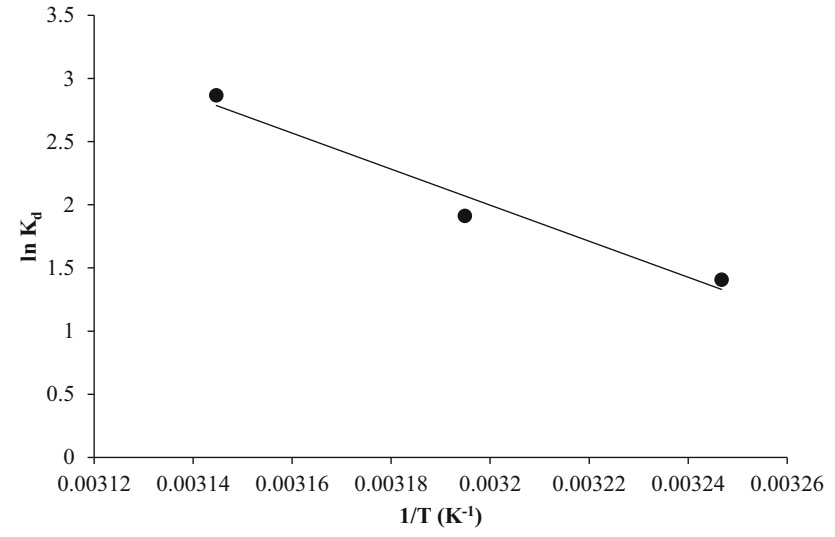

Fig. 10 Plot of $\ln K_{\mathrm{L}}$ versus $1 / T$ for estimation of thermodynamic parameters for the electrocoagulation removal of rhodamine blue dye

Table 4 Thermodynamic parameters for the removal of bromophenol blue

\begin{tabular}{llllll}
\hline $\begin{array}{l}\text { Temp } \\
(\mathrm{K})\end{array}$ & $\ln K$ & $\begin{array}{l}\Delta G \\
(\mathrm{~J} \mathrm{~mol}\end{array}$ & $\begin{array}{l}\Delta S \\
\left(\mathrm{~J} \mathrm{~mol}^{-1} \mathrm{~K}^{-1}\right)\end{array}$ & $\begin{array}{l}\Delta H \\
\left(\mathrm{~kJ} \mathrm{~mol}^{-1}\right)\end{array}$ & $R^{2}$ \\
\hline 303 & 1.407 & -1423.29 & 396.28 & 118.65 & 0.996 \\
308 & 1.912 & -3404.68 & & & \\
313 & 2.867 & -5386.08 & & & \\
\hline
\end{tabular}

Current density: $71.5 \mathrm{~A} \mathrm{~m}^{-2}$; $\mathrm{NaCl}$ conc: $2 \mathrm{~g} \mathrm{~L}^{-1}$; $\mathrm{pH}: 7.0$

1/T plot in Fig. 10. The thermodynamic parameters are given in Table 4. From the table, it is found that the negative value of $\Delta G$ indicates the spontaneous nature of adsorption. Positive value of enthalpy change indicates that the adsorption process is endothermic in nature, and the negative values of change in internal energy $(\Delta G)$ show the spontaneous adsorption of RhB on the coagulant. Positive value of entropy change shows the increased randomness of the solution interface during the adsorption process (Table 4).

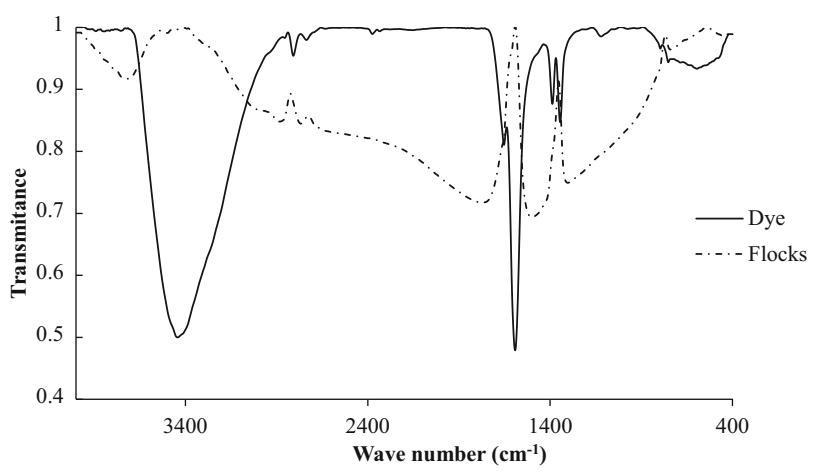

Fig. 11 FTIR of the solution of BPB dye solution before and after removal

FTIR studies of the dye solution

before and after electrocoagulation

Figure 11 presents the FTIR spectrum of the dye solution before and after the process. Before the electrocoagulation, the spectrum shows the following: Sharp and strong peaks at $3456.8 \mathrm{~cm}^{-1}$ could be assigned to $-\mathrm{OH}$ stretch on the carboxyl of the dye molecule, while that at $2821 \mathrm{~cm}^{-1}$ is due to $-\mathrm{CH}-$. Those at 1593 and $1350 \mathrm{~cm}^{-1}$ are due to the aromatic $\mathrm{C}=\mathrm{C}$ stretching. After electrocoagulation, the extra structure noted such as that at $3759 \mathrm{~cm}^{-1}$ may be assigned to the $(\mathrm{O}-\mathrm{H})$ stretching vibration in the $\mathrm{Fe}(\mathrm{OH})_{3}$ structures and the broadening of peaks is attributed to dye molecule conjugation with $\mathrm{Fe}(\mathrm{III})$ ions.

\section{Conclusion}

This study revealed the feasibility of the use of electrocoagulation techniques for removing rhodamine B from its aqueous solution in a process. The process depends on numerous factors such as current density, solution $\mathrm{pH}$, temperature, initial dye concentration and contact time. 
The percentage removal of the dye increased with $\mathrm{pH}$ up to $\mathrm{pH} 7$, and also contact time and current density increase influence the removal positively. Equilibrium data fitted very well in the Langmuir isotherm equation, confirming the monolayer adsorption capacity of $163.63 \mathrm{mg} \mathrm{g}^{-1}$ at $303 \mathrm{~K}$. The kinetics of the process is best explained using a pseudo-first-order kinetics model, with higher $R^{2}$ (Table 2). Intraparticle diffusion was not the sole rate-controlling factor. The thermodynamics parameters obtained indicate that the process is spontaneous endothermic nature of the process. Therefore, the present findings suggested a better performance of electrocoagulation with $\mathrm{Al}$ electrode as an inexpensive method for the removal of $\mathrm{RhB}$ aqueous solutions.

Acknowledgments The financial support in the form of grants from CSIR, for 12 months TWAS-CSIR Postdoctoral Fellowship, FR number: 3240275035, awarded to Abideen Idowu Adeogun that enables this work to be carried out. Also he is thankful to the authority of the Federal University of Agriculture, Abeokuta, Nigeria, for granting the study leave to honour the fellowship.

Open Access This article is distributed under the terms of the Creative Commons Attribution 4.0 International License (http:// creativecommons.org/licenses/by/4.0/), which permits unrestricted use, distribution, and reproduction in any medium, provided you give appropriate credit to the original author(s) and the source, provide a link to the Creative Commons license, and indicate if changes were made.

\section{References}

Adeogun AI, Bello OS, Adeboye MD (2010) Biosorption of lead ions on biosorbent prepared from plumb shells (Spondias mombin): kinetics and equilibrium studies. Pak J Sci Ind Res 53:246-251

Adeogun AI, Ofudje AE, Idowu MA, Kareem SO (2011) Equilibrium, kinetics, and thermodynamics studies of the biosorption of $\mathrm{Mn}(\mathrm{II})$ ions from aqueous solution by raw and acid-treated corncob biomass. BioResources 6:4117-4134

Adeogun AI, Kareem SO, Durosanya JB, Balogun SE (2012) Kinetics and equilibrium parameters of biosorption and bioaccumulation of lead ions from aqueous solutions by Trichoderma longibrachiatum. J Microbiol Biotechnol Food Sci 1:1221-1234

Aleboyeh A, Daneshvar N, Kasiri MB (2008) Optimization of C.I. acid red-14 azo dye removal by electrocoagulation batch process with response surface methodology. Chem Eng Process 47:827-832

Ali M, Sreekrishnan TR (2001) Aquatic toxicity from pulp and paper mill effluents-a review. Adv Environ Res 5:175-196

Amini M, Younesi H, Bahramifar N, Lorestani AA, Ghorbani F, Daneshi A, Sharifzadeh M (2008) Application of response surface methodology for optimization of lead biosorption in an aqueous solution by Aspergillus niger. J Hazard Mater 154:694-702

Aniruldhan TS, Radhakrishnan PG (2008) Thermodynamics and kinetics of adsorption of $\mathrm{Cu}$ (II) from aqueous solutions onto a new cation exchanger derived from tamarind fruit shell. J Chem Thermodyn 40:702-709
Avrami M (1940) Kinetics of phase change: transformation-time relations for random distribution of nuclei. J Chem Phys $8: 212-224$

Bello OS, Adeogun AI, Ajaelu JC, Fehintola EO (2008) Adsorption of methylene blue onto activated carbon derived from periwinkle shells: kinetics and equilibrium studies. Chem Ecol 24:285-295

Carneiro PA, Osugi ME, Fugivar CS, Boralle N, Furlan M, Zanoni MV (2005) Evaluation of different electrochemical methods on the oxidation and degradation of Reactive Blue 4 in aqueous solution. Chemosphere 59(3):431-439

Chen Z, Ma W, Han M (2008) Biosorption of nickel and copper onto treated alga (Undariapinnarlifida): application of isotherm and kinetics models. J Hazard Mater 155:327-333

Daneshvar N, Salari D, Khataee AR (2003) Photocatalytic degradation of azo dye acid red 14 in water: investigation of the effect of operational parameters. J Photochem Photobiol, A 157:111-116

Daneshvar N, Oladegaragoze A, Djafarzadeh N (2006) Decolorization of basic dye solutions by electrocoagulation: an investigation of the effect of operational parameters. J Hazard Mater 129(1):116-122

Dubinin MM, Radushkevich LV (1947) Equation of the characteristic curve of activated charcoal. In: Proceedings of the academy of sciences, physical chemistry section, U.S.S.R. vol 55, pp 331-333

Freundlich HMF (1906) Over the adsorption in solution. J Phys Chem $57: 385-471$

Fu L, Xu BT, Xu XR, Gan RY, Zhang Y, Xia EQ (2011) Antioxidant capacities and total phenolic contents of 62 fruits. Food Chem 129:345-350

Kolpin DW, Furlong ET, Meyer MT, Thurman EM, Zaugg SD, Barber LB, Buxton HT (2000) Pharmaceuticals, hormones and other organic wastewater contaminants in US streams, 1999-2000: a national reconnaissance. Environ Sci Technol 36(6):1202-1211

Kundu S, Gupta AK (2006) Investigation on the adsorption efficiency of iron oxide coated cement (IOCC) toward s As(V)-kinetics, equilibrium and thermodynamic studies. Colloidal Surf A273:121-128

Langmuir I (1918) The adsorption of gases on plane surfaces of glass, mica and platinum. J Am Chem Soc 40:1361-1403

Lin Y, He X, Han G, Tian Q, Hu W (2011) Removal of crystal violet from aqueous solution using powdered mycelial biomass of Ceriporia lacerata P2. J Environ Sci 23:2055-2062

Malik PK (2004) Dye removal from wastewater using activated carbon developed from sawdust: adsorption equilibrium and kinetics. J Hazard Mater 113:81-88

Mollah MYA, Morkovsky P, Gomes JAG, Kesmez M, Parga J, Cocke DL (2004) Fundamentals, present and future perspectives of electrocoagulation. J Hazard Mater B 114(2004):199-210

Panizza M, Michaud PA, Cerisola G, Comninellis C (2001) Electrochemical treatment of wastewaters containing organic pollutants on boron-doped diamond electrodes: prediction of specific energy consumption and required electrode area. Electrochem Commun 3:336-339

Perez-Marin AB, Meseguer-Zapata V, Ortuño JF, Aguilar M, Sáes J, Lloréns $M$ (2007) Removal of cadmium from aqueous solutions by adsorption onto orange waste. J Hazard Mater 139:122-131

Rajgopalan S (1995) Water pollution problem in the textile industry and control. In: Trivedy RK (ed) Pollution management in industries. Environmental Publications, Karad, pp 21-44

Redlich O, Peterson DL (1959) A useful adsorption isotherm. J Phys Chem 63:1024-1026

Richardson SD, Wilson CS, Rusch KA (2004) Use of rhodamine water tracer in the marshland upwelling system. Ground Water 42(5):678-688 
Rochat J, Demenge P, Rerat JC (1978) Toxicologic study of a fluorescent tracer: rhodamine B. Toxicol Eur Res 1:23-26

Routh T (1998) Anaerobic treatment of vegetable tannery wastewater by UASB process. Ind J Environ Prot 20(2):115-123

Saha P, Sanyal SK (2010) Assessment of the removal of cadmium present in wastewater using soil-admixture membrane. Desalination 259:131-139

Senthilkumar S, Bharathi S, Nithyanandhi D (2000) Biosorption of toxic heavy metals from aqueous solution. Bioresour Technol 75:163-165

Shawabkeh RA, Tutunji MF (2003) Experimental study and modeling of basic dye sorption by diatomaceous clay. Appl Clay Sci 24(1-2):111-120

Sips R (1948) Combined form of Langmuir and Freundlich equations. J Chem Phys 16:490-495

Sun QY, Yang LZ (2003) The adsorption of basic dyes from aqueous solution on modified peat-resin particle. Water Res 37:1535-1544

Tempkin MI, Pyzhev V (1940) Kinetics of ammonia synthesis on promoted iron catalyst. Acta Phys Chim USSR 12(1940):327-356
Vaghetti JCP, Lima EC, Royer B, Cunha BM, Cardoso NF, Brasil JL, Dias SLP (2009) Pecan nutshell as biosorbent to remove $\mathrm{Cu}(\mathrm{II})$, $\mathrm{Mn}$ (II) and $\mathrm{Pb}(\mathrm{II})$ from aqueous solutions. J Hazard Mater 162:270-280

Wang ZX, Xu XC, Gong Z, Yang FY (2012) Removal of COD phenols and ammonium from Lurgi coal gasification wastewater using A ${ }^{2} \mathrm{O}-\mathrm{MBR}$ system. J Hazard Mater 78(1):235-236

Weber WJ Jr, Morris JC (1963) Kinetics of adsorption on carbon from solution. J Sanit Eng Div ASCE 89:31-59

Zeldowitsch J (1934) Über den mechanismus der katalytischen oxydation von $\mathrm{CO}$ an $\mathrm{MnO}_{2}$. Acta Physicochem URSS $1: 364-449$

Zucca P, Vinci C, Sollai F, Rescigno A, Sanjust E (2008) Degradation of Alizarin Red $\mathrm{S}$ under mild experimental conditions by immobilized 5,10,15,20-tetrakis(4-sulfonatophenyl) porphine$\mathrm{Mn}$ (III) as a biomimetic peroxidase-like catalyst. J Mol Catal A Chem 288:97-102 